\title{
Some Medicinal Plants with Antidiabetic Activity: A Review
}

\author{
Varsha Nigam $^{1}$, Neelam Behl ${ }^{2}$ \\ ${ }^{1}$ Assistant Professor, Department of Botany, Guru Nanak Khalsa College, Yamuna Nagar -135001, Haryana \\ ${ }^{2}$ Assistant Professor, Department of Zoology, Guru Nanak Khalsa College, Yamuna Nagar -135001, Haryana
}

\begin{abstract}
Diabetes has been recognized by ancient physicians and its main symptoms were known by the increased thirst, frequent urination, and tiredness. Herbal medicines have been the highly esteemed source of medicine throughout human history. The WHO has defined herbal medicines as finished labelled medicinal products that contain as active ingredients aerial or underground parts of plants or other plant material or combination thereof, whether in cruds state or as plant preparations. The present article is an attempt to highlight some traditional plants used to cure diabetes. This review presents the profile of plants include information about the scientific name, family, hypoglycaemic activity and the active constituents. WHO has pointed out this prevention of diabetes and its complications is not only a major challenge for the future, but essential if health for all is to attain. Acquiring knowledge about diabetes is an essential part of diabetes management, and even more important is to make the patient aware of this chronic disease.
\end{abstract}

Keywords: Medicinal plants, Diabetes, hypoglycaemic, insulin

\section{Introduction}

Medicinal plants continue to be an important therapeutic aid for alleviating ailments of humankind. Over the last 2500 years, there have been very strong traditional systems of medicine such as Chinese, Ayurvedic, and the Unani, born and practiced, more in the eastern continent. These traditions are still flourishing, since; approximately $80 \%$ of the people in the developing countries rely on these systems of medicine for their primary health care needs ${ }^{1}$. Diabetes mellitus is caused by the abnormality of carbohydrate metabolism which is linked to low blood insulin level or insensitivity of target organs to insulin. ${ }^{2}$ Type 1 diabetes can affect children or adults, but was traditionally termed "juvenile diabetes" because a majority of these diabetes cases were in children. It leads to inability to release insulin results in low rates of glucose uptake into muscles and adipose tissue. ${ }^{3}$ If the amount of insulin available is insufficient, or if the insulin itself is defective, then glucose will not be absorbed properly by the body cells that require it, and it will not be stored appropriately in the liver and muscles. The net effect is persistently high levels of blood glucose. ${ }^{4}$ When the glucose concentration in the blood remains high over time, the kidneys will reach a threshold of reabsorption and glucose will be excreted in the urine (glycosuria). ${ }^{5}$ This increases the osmotic pressure of the urine and inhibits reabsorption of water by the kidney, resulting in increased urine production (polyuria) and increased fluid loss causing dehydration and increased thirst (polydipsia) ${ }^{6}$.Type 2 diabetes usually occurs in obese individuals and is associated with hypertension and dyslipidemia. Thus the treatment aims to reduce insulin resistance and to stimulate insulin secretion. ${ }^{3,7}$ Traditional medicine (herbal) is used for treatment of diabetes in developing countries where the cost of conventional medicines is a burden to the population. ${ }^{8}$

According to $\mathrm{WHO}, 80 \%$ of the population rely on plants derived medicine for their health care. ${ }^{9}$ Natural remedies from plants are considered to be effective and risk- free. ${ }^{10}$
The ethnobotanical information reports about 800 plants that may possess antidiabetic potential. ${ }^{7}$ In Ayurveda various herbs are reported for treating and preventing diabetes. ${ }^{11}$

Some medicinal plants used for treatment and management of diabetes

Annona squamosa Linn 12, 13, 14

(Annonaceae)

Commonly called custard apple in English and sharifa in Hindi. It is cultivated throughout India. The pharmacological active ingredients are present in seeds, leaves and aerial parts of the plant ${ }^{12}$. The research reveals that the plant possesses both hypoglycaemic and antidiabetic activity. It acts by enhancing insulin level from the pancreatic islets, increases utilization of glucose in muscle and inhibits the glucose output from liver. Its margin of safety is high. The extract obtained from leaves of this plant is useful in maintaining healthy blood sugar and cholesterol levels ${ }^{13 .}$ Another spp. Annona muricata Linn. Commonly called soursop. It is small evergreen tree growing 5 to 6 meters in height. Young branches arerustyhairy, the malodorous leaves, and the plant isevergreen. Annona muricata is indigenous to mostof the warmest tropical areas in South and North America, including the Amazon. The researchers revealed the immunohistochemical and biochemical effects of aqueous extract of leaves on pancreatic $\beta$ cells of STZ (streptozotocin) treated diabetic rats. A. muricata Linn. leaf extract played importantrole in reduction of oxidative stress on pancreatic $\beta$ cells of streptozotocin treated diabetic rats. The treatment increased the area of insulin immunoreactive $\beta$-cells and partially prevents degeneration of $\beta$-cells ${ }^{14}$. Murraya koenigii Linn. ${ }^{14,15}$

(Rutaceae)

Murraya koenigii is commonly known as Curry patta and is widely used condiment and spice in India. In normal and alloxan diabetes the aqueous extract of the leaves of $M$. koenigii produce dhypoglycemic effect. Oral feeding of 


\section{International Journal of Science and Research (IJSR) \\ ISSN (Online): 2319-7064}

Index Copernicus Value (2016): 79.57 | Impact Factor (2015): 6.391

this plant for 60 days diet to normal rats showed an increase in the concentration of hepatic glycogen due to hypoglycemic activity. It has been reported that feeding different doses of $M$. Koenigii leaves to diabetic rats play a role in control of mild diabetic rats to moderate, severe and type I diabetes. It suppresses blood glucose level and was found to have beneficial effect on carbohydrate metabolism ${ }^{14,15}$.

\section{Boerhaavia diffusa Linn. ${ }^{14,15,16,17,18,19,20}$ (Nyctaginaceae)}

Boerhaavia diffusa is commonly known as 'Redhogweed". The root and the whole plant are used as an Ayurvedic medicine in India and Unani medicine for the treatment of diabetes, stress, dyspepsia, abdominal pain, inflammation, jaundice, enlargement of spleen, congestive heart failure and bacterial infections. ${ }^{14-17}$ Aqueous leaf extract of the plant has been studied for its antidiabetic effect in alloxan-induced diabetic rats 18,19 . The antidiabetic activity of the chloroform extract of the plant leaves on chronic treatment of streptozotocin induced NIDDM (non insulin dependent diabetes mellitus) model diabetic rats was evaluated and the herb possesses antidiabetic activity. The herb mainly acts by reducing blood glucose level and increasing insulin senitivity ${ }^{20}$.

\section{Allium cepa $\mathbf{L}^{21,22,23}$ \\ (Liliaceae)}

Allium cepa is known only in cultivation but related wild species occur in Central Asia. Various ether soluble fractions as well as insoluble fractions of dried onion powder show anti-hyperglycemic activity in diabetic rabbits. A. cepa also known to have antioxidant and hypolipidemic activity Administration of a sulfur containing amino acid, S-methyl cysteine sulphoxide (SMCS) $(200 \mathrm{mg} / \mathrm{kg}$ for 45 days) to alloxan induced diabetic rats significantly controlled blood glucose as well as lipids in serum and tissues. ${ }^{21}$ It normalizes the activities of liver hexokinase, glucose 6-phosphatase and HMG Co A reductase. When diabetic patients were given single oral dose of $50 \mathrm{~g}$ of onion juice, it significantly controlled postprandial glucose levels. ${ }^{22,23}$

\section{Azadirachta indica A. Juss. ${ }^{21,24}$ (Meliaceae)}

Commonly known as Neem. It is a tree native to India, Burma, Bangladesh, Sri Lanka, Malaysia and Pakistan, growing in tropical and semi-tropical regions. A low $(0.5 \mathrm{~g}$ tid) and high (2g tid) doses of powdered part, aqueous extract and alcoholic extract of $A$. indica shows significant hypoglycemic activity in high dose and can be successfully combined with oral hypoglycemic agents in type-2 diabetic patients whose diabetes is not controlled by these agents.

Eclipta alba (L) Hassk. ${ }^{21,25}$

\section{(Asteraceae)}

It is widely distributed throughout India, China, Thailand, and Brazil. Oral administration of leaf suspension of $E$. alba ( 2 and $4 \mathrm{~g} / \mathrm{kg}$ body weight) for 60 days results in significant reduction in blood glucose, glycosylated haemoglobin $\mathrm{HbA}(\mathrm{l}) \mathrm{c}$. The extract decreases the activities of glucose-6- phosphatase and fructose-1, 6bisphosphatase, and increase the activity of liver hexokinase. Thus, oral administration of E. alba possess potent antihyperglycemic activity.

\section{Coriandrum sativum $\mathbf{L}^{26,27}$ (Apiaceae)}

An annual herb native to southern Europe and North Africa to southwestern Asia. Coriander seed extract (200 $\mathrm{mg} / \mathrm{kg}$ ) significantly increases the activity of the beta cells in comparison with the diabetic control rats and decreases serum glucose in streptozotocin-induced diabetic rats and releases insulin from the beta cells of the pancreas. The extract shows antihyperglycemic, insulin-releasing and insulin-like activity.

\section{Momordica charantia Linn. ${ }^{28,29,30}$ (Cucurbitaceae)}

Momordica Charantia, commonly known as "karela" also contains a polypeptide pinsulin similar to bovine insulin in normalizing the blood sugar level, and, therefore, has been used as a folk medicine for diabetes.Bitter gourd makes the receptors of target cells (like muscles and fat tissues) more sensitive to insulin, and therefore, the cells increase their absorption of glucose. At least three different groups of constituents in the bitter gourd appeared to have hypoglycemic, blood sugar lowering, actions of potential benefit in diabetes mellitus. It is believed that these include a mixture of steroidal saponins known as charantin, insulin-like peptides, and alkaloids. The bitter melon is believed to improve glucose tolerance in Type II diabetes. Active constituents are believed to be oleanolic acid glycosides and Momordins which prevent absorption of sugar. 


\section{International Journal of Science and Research (IJSR) \\ ISSN (Online): 2319-7064}

Index Copernicus Value (2016): 79.57 | Impact Factor (2015): 6.391

Some medicinal plants used for treatment and management of diabetes

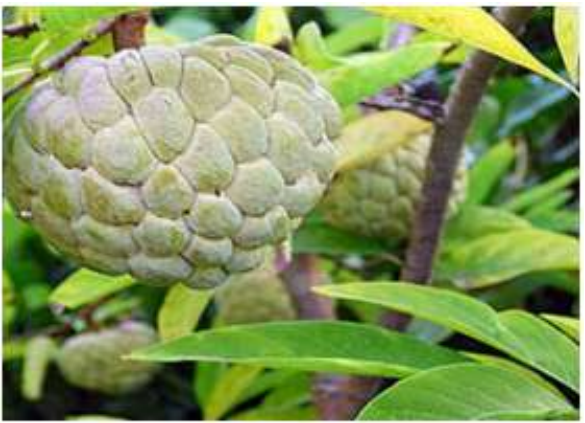

Annona squamosa Linn

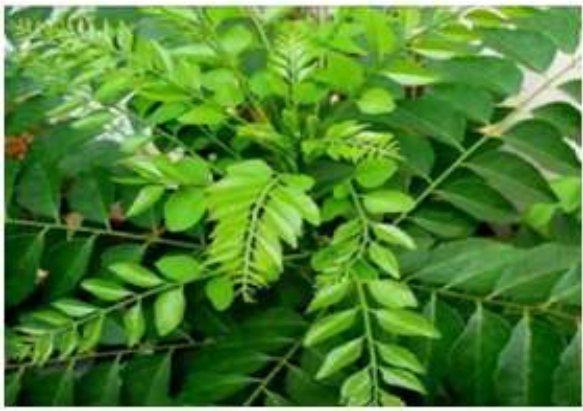

Murraya koenigii Linn.

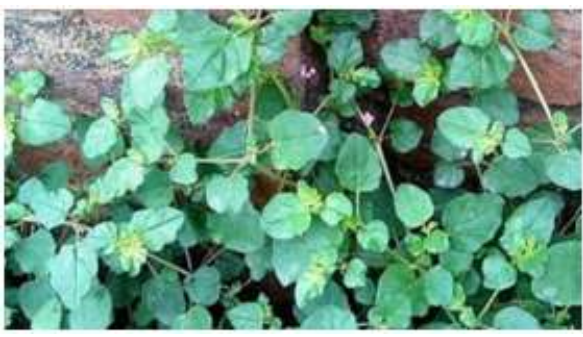

Boerhaavia diffusa Linn.

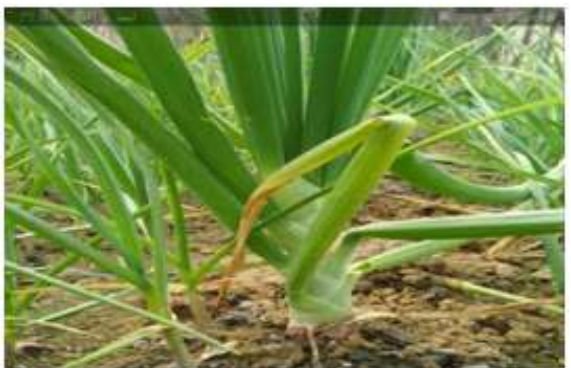

Allium cepa $\mathrm{L}$

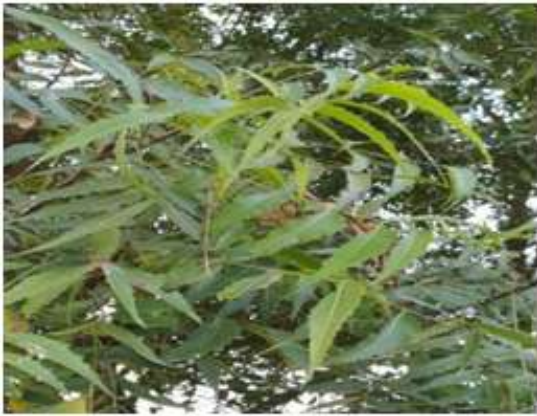

Azadirachta indica A. Juss.

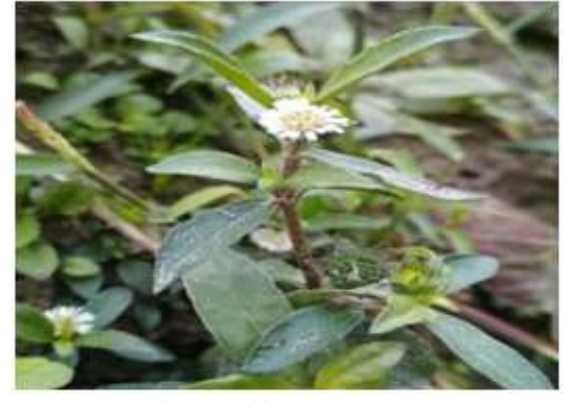

Eclipta alba (L) Hassk.

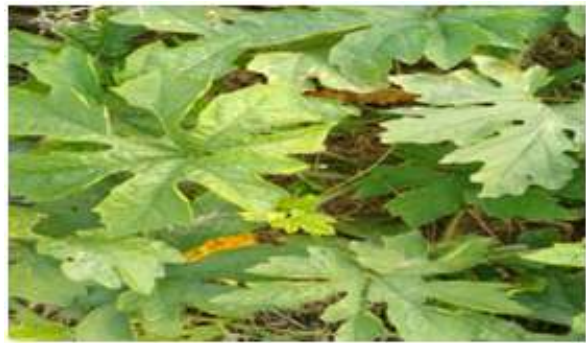

Momordica charantia Linn.

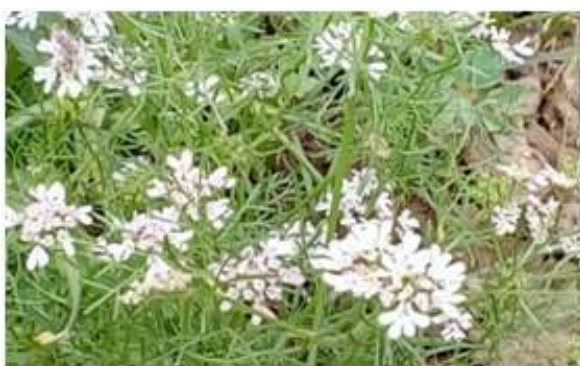

Coriandrum sativum $\mathbf{L}$.

\section{Conclusion}

At present, the treatment of diabetes mainly involves a sustained reduction in hyperglycemia by the use of biguanides, thiazolidinediones, sulphonylureas, Dphenylalanine derivatives, meglitinides and $\alpha$-glucosidase inhibitors in addition to insulin ${ }^{29}$. Currently, many countries face large increases in the number of people suffering from diabetes. The World Health Organization estimated that about 30 million people suffered from diabetes in 1985 and the number increased to more than 171 million in 2000. It is estimated that the number will increase to over 366 million by 2030 and that large increases will occur in developing countries, especially in people aged between 45 and 64 years $^{30,} 32$. Many traditional plant treatments for diabetes are used throughout the world. Plant drugs and herbal formulations are frequently considered to be less toxic and free from side effects than synthetic ones. Based on the WHO recommendations, hypoglycemic agents of plant origin used in traditional medicine are important ${ }^{33}$.

In conclusion, this paper has presented a list of antidiabetic plants used in the treatment of diabetes mellitus. It showed that these plants have hypoglycaemic effects. Some of these plant derived medicines, however, offer potential for cost effective management of diabetes

Volume 6 Issue 12, December 2017 www.ijsr.net 


\section{International Journal of Science and Research (IJSR) \\ ISSN (Online): 2319-7064 \\ Index Copernicus Value (2016): 79.57 | Impact Factor (2015): 6.391}

through dietary interventions, nutrient supplementation, and combination therapies with synthetic drugs in the short term, and as the sole medication from natural sources over the long term.

\section{Acknowledgement}

We are thankful to the authors of all those articles has been reviewed and discussed here and greatly acknowledge to Dr. Mandeep Singh, Principal, Guru Nanak Khalsa College, Yamuna Nagar for the support and encouragement throughout the work.

\section{References}

[1] ANM Mamun-Or-Rashid et. al"a review on medicinal plants with antidiabetic activity" Journal of Pharmacognosy and Phytochemistry 2014; 3(4): 149159.

[2] Maiti R, Jana D, Das UK, Ghosh D. Antidiabetic effect of aqueous extract of seed of Tamarindus indica in streptozotocin induced diabetic rats. J Ethnopharmaco 2004; 92: 85-91.

[3] AL Lehninger, DL Nelson, MM Cox. Principle of Biochemistry. New York: Worth Publishers; 2010.

[4] Shoback, edited by David G. Gardner, Dolores (2011). Greenspan's basic \& clinical endocrinology (9th ed.). New York: McGraw-Hill Medical. ISBN 9780071622431.

[5] Robert K. Murray... [et (2012). Harper's illustrated biochemistry (29th ed.). New York: McGraw-Hill Medical. ISBN 007176576X.

[6] Arumugam.G, and et.al."A review: Anti diabetic medicinal plants used for diabetes mellitus", Journal of Acute Disease (2013)196-200.

[7] Saravanan G, Pari L. Hypoglycaemic and antihyperglycaemic effect of Syzygium cumini bark in streptozotocin-induced diabetic rats. J Pharmacol Toxicol 2008; 3: 1-10.

[8] Fakim AG. Medicinal plants: Traditions of yesterday and drugs of tomorrow. Molecular Aspects of Medicine, 2006, 27: 1-93.

[9] Gupta RK, Kesari AN, Watal G, Murthy PS, Chandra R, Maithal K, Tandon V. Hypoglycaemic and antidiabetic effect of aqueous extract of leaves of Annona squamosa (L.) in experimental animal. Current Science, 2005, 88:1244-1254.

[10] Alarcon-Aguilara FJ, Roman-Ramos R, Perez-Gutierrez S, Aguilar-Contreras A, Contreras-Weber CC, FloresSaenz JL. Study of the anti-hyperglycemic effect of plants used as antidiabetics. J Ethnopharmacol 1998; 61: $101-110$

[11] Akanksha, Srivastava, A.K., Maurya, R. (2010). Antihyperglycemic activity of compounds isolated from Indian medicinal plants. Indian journal of experimental biology. 43:294-298.

[12] . Kirtikar KR, Basu BD. Indian Medicinal Plants. 2nd ed. Dehradun: Oriental Enterprises, 2003, 1219. Watt G.: Periodical Experts: A Dictionary of theEconomical Products of India, p. 260, Cosmo Publications, Delhi 1972

[13] .Gupta R.K., Kesari A.N., Watal G., et al.: Curr.Sci. 88, 1244 (2005).

[14] Neelesh Malviya, Sanjay Jain And Sapna Malviya, Antidiabetic Potential Of Medicinal Plants, Acta
Poloniae Pharmaceutica ñ Drug Research, Vol. 67 No. 2 pp. 113-118, 2010, ISSN 0001-6837

[15] Nadkarni K.M.: Indian Materia Medica, 3rd ed., pp. 202-207 Popular Book Depot, Mumbai 1954.

[16] Kirtikar K.R., Basu B.D.: Indian Medicinal Plants, 2nd ed., pp. 1052-1054, Lalit Mohan Basu Publications, Allahabad 1933.

[17] Chopra R.W., Chopra I.C., Handa K.L., et al.:Indigenous Drugs of India, 2nd ed., pp. 314-316, Dhar and Sons Ltd., Calcutta 1958.

[18] Chude M.A., Orisakwe O.J., Afonne O.J., et al.:Ind. J. Pharmacol. 33, 215 (2001).

[19] Pari L., Satheesh M.A.: J. Ethnopharmacol. 91, 109 (2004).

[20] Rao K.N., Krishna M.B., Srinivas N.: Trop. J.Pharm. Res. 3, 305 (2004)

[21] 25.G.B. Kavishankar \&et.al Diabetes and medicinal plants-A review, Int J Pharm Biomed Sci 2011, 2(3), 6580 ISSN No: 0976-5263.

[22] Kumari K, Mathew BC, Augusti KT. Antidiabetic and hypoHpidaemic effects of S-methyl cysteinesulfoxide, isolated from Allium cepa Linn. Ind J Biochem Biophys 1995, 32, 49-54.

[23] Mathew PT, Augusti KT. Hypoglycemic effects of onion, Allium cepa Linn, on diabetes mellitusapreliminary report. Ind J Physiol Pharmacol 1975, 19, 213-217.

[24] Waheed A, Miana GA, Ahmad SI.Clinical investigation of hypoglycemic effect of seeds of Azadirachta-inidca in type-2(NIDDM) diabetes mellitus. Pak J Pharm Sci 2006, 19, 322-325.

[25] Ananthi J, Prakasam A, Pugalendi KV. Antihyperglycemic activity of Eclipta alba leaf on alloxan-induced diabetic rats. Yale J Biol Med 2003, 76, 97-102.

[26] Eidi M, Eidi A, Saeidi A, Molanaei S, Sadeghipour A, Bahar M, Bahar K. Effect of coriander seed (Coriandrum sativum L.) ethanol extract on insulin release from pancreatic beta cells in streptozotocin-induccd diabetic rats. Phytother Res 2009, 23, 404-406.

[27] Gray AM, Flatt PR. Insulin-releasing and insulin-like activity of the traditional anti-diabetic plant Coriandrum sativum (coriander). Br J Nutr 1999, 81, 203-209.

[28] Mitra, A., and Bhattacharya, D. (2006). "Effect of Fatty Substances on Health particularly to Patients Suffering from NIDDM and Dyslipidaemia." J. Interacademicia. 10(1): 74-85.

[29] Mitra. A. (2007). Effects of composite of tulsi leaves, amla, bitter gourd, gurmur leaves, jamun fruit and seed in type 2 diabetic patients. Journal of clinical and diagnostic research. [serial online]6:511-520.

[30] Raman, A., and Lau, C. (1996). Anti-diabetic properties and phytochemistry of Momordica charantia. Phytomedicine, 2(4): 349-62.

[31] World Health Organization. Retrieved 4 April 2014." About Diabetes".

[32] Wild, S., G. Roglic and A. Green, 2004. Title ...??? Diabetes Care, 27: 1047

[33] Rawat Mukesh and Parmar Namita, Medicinal Plants with Antidiabetic Potential - A Review, AmericanEurasian J. Agric. \& Environ. Sci., 13 (1): 81-94, 2013 ISSN 1818-6769 